\section{THE SOCIAL MARKET ECONOMY MODEL - CAN IT BE EMULATED IN THE GLOBAL SOUTH?}

\section{Sumanasiri Liyanage}

Dean, Faculty of Management and Finance, SANASA

Campus Ltd., Sri Lanka

\section{Chamari Jayani Wijayawardane \\ Assistant Lecturer, SANASA Campus Ltd., Sri Lanka}

\section{PERSPECTIVES}

Sri Lanka Journal of Economic Research Volume 4 (1) December 2016 SLJER.04.01.P2: pp. 123-134 Sri Lanka Forum of University Economists

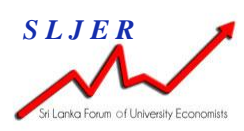

\title{
INTRODUCTION
}

The concept of a social market economy (SME) came to play a significant role in Sri Lankan development discourse when it was revealed in late-2014 at the height of the presidential election, that the new government under Maithreepala Sirisena and- Ranil Wickramasinghe would follow the SME model in articulating its economic policies: likely the first time such an idea had surfaced in a Sri Lankan election campaign. Karu Jayasuriya, the Speaker of Parliament, stated at the time that an SME would contribute to achieving the fivefold development strategy suggested by Prime Minister Ranil Wickramasinghe, so that it would uplift the economic standards of the people and create an equitable society (Sri Lanka putting together Social Market Economy Model, 2015).

The fivefold development plan titled 'Our Solutions to Your Problems' has been formulated targeting five main areas: (economy, infrastructure facilities, prevention of frauds and malpractices as well as freedom and education).

According to the Prime Minister, it will give priority to improving the economy such that more youth may be employed and the incomes of people may increase within a period of 60 months. The plan will next address the improvement of people's general welfare and infrastructure facilities. He states that the major objective is to create a new society and a competitive economy as well as to safeguard the equal rights of the people, for which purpose the support of the entire Parliament is needed (ColomboPage, 2015).

Speaking at the event in which the five-point plan to develop the country in 60 months was unveiled, the Prime Minister said the United National Front for Good Governance (UNFGG) government will create a social market economy where the environment and the social security of the people is protected while encouraging competition. UNFGG promised to create one million jobs increasing the competitiveness of Sri Lankan industries, agriculture and fisheries, creating 2,500 cluster villages to allow community 
leaders to resolve issues pertaining to villages and to promote environmentally friendly agriculture (Kuruwita, 2015).

Sri Lanka should urgently bring legislations to give effect to the policy reforms required to make it a highly competitive social market economy. Deputy Minister Harsha de Silva said that he believed that the third generation economic reforms have exceeded expectations in restructuring the economy to prepare for the next wave of sustainable growth in Sri Lanka (LBO, 2015).

While there have been positive reviews for the Economic Policy Statement put forward by Prime Minister Ranil Wickremesinghe, economists were quick to point out that there were severe deficiencies in the modalities of his concepts. The Prime Minister made special mention of the 'amalgamation of the EPF and the EFT funds' citing that the Government would secure the funds in the EPF and ETF and amalgamate them to create a new national pension fund with a combined value of Rs. 1.7 trillion (Sirimane, 2015).

Certain excerpts from the statement issued by Dr. de Silva appear below:

"The proposed restructuring of state owned enterprises and the creation of holding corporation to manage them by a board appointed by the constitutional council and the creation of the national wealth fund, (amalgamating the EPF and ETF) to be managed by an independent body that includes trade unions is a most important break from the past to deal with the past where chronic losses were recouped by regressive taxes on the people while the savings of the hard working people were plundered." (PM articulates programme to create highly competitive social market economy in Sri Lanka- Harsha, 2015).

In introducing SME in Sri Lanka the new government intended to introduce an economic model where the principal driver was not the State but the market. The State, in addition to its traditional function would intervene, if necessary, in looking after the welfare of the vulnerable by introducing an inclusive social security system.

What is SME? What are its main characteristics? How did it develop? Does it differ from the Social Democratic Model in Europe? Is the SME still implemented today? Is it suitable for the present condition of the world? And most importantly, is it suitable for a country like Sri Lanka? These are the principal questions we intend to address in the paper. Section 1 describes briefly the main characteristics of SME while section 2 focuses on the impact of SME on post-War Germany. Finally, section 3 discusses why SME cannot be emulated in the South. The main objectives are to (1) identify the social market economy, (2)discover if it is still implemented and if so, in which countries it is implemented, (3) recognise if it suits a developing country like Sri Lanka and (4) Identify if it can be practiced in the future. 


\section{Basic Tenets of SME: Development of the Theory and how it differs from Social Democracy}

\section{What is SME?}

There are various definitions as to what the SME is. Tribe (1995, p.203) defines that it is understood as a code-word for prudent economic-centrism. It is a capitalism with an acceptable, human face in which greater emphasis is placed upon legal regulation as the means of identifying and achieving social objectives. Hildebrand (2009, p. 8) states that the social market economy has its origin in Germany (known as Soziale Marktwirtschaft). It seeks a middle path between socialism and capitalism by aiming to maintain a balance between a high rate of economic growth, low inflation, low levels of unemployment, good working conditions, social welfare, and public services, by using State intervention. While respecting the free market, the social market economy is opposed to both a planned economy and laissez-faire capitalism. A free market economy is social in its origin.

According to Hook (2004, p.1) and Koslowaski (1998, pp. 256-258), the social market economy is a social and economic order, introduced by Economics Minister Ludwig Erhad in 1948 which ended the Nazi-era of controlled regime, ushered in West Germany's 'economic miracle', and offered a socially-conscious model of market capitalism. It served as an explanation for West Germany's economic and social success in the decades following World War II. The concept of social market economy has different backgrounds. Its roots lie in dynamic theory and philosophical anthropology. It is best described as an ideological concept where a co-ordination of form is striven after, between the spheres of life represented by the market, the State and the social groups. It is as much sociological as economic, as much static as dynamic. The social goals are equally important as economic goals, and thus combine economic and social policy'.

\section{Historical Antecedents of Social Market Economy Model}

The concept of the social market economy as an economic system was developed by Ludwig Erhard on the basis of the ideas of economists such as Muller-Armack, according to Roberts (2000, p. 43). As discussed by Nicholls (1994, p. 151), when the Americans liberated Furth in April 1945, they asked him to cover the economic administration for the area. A great issue had arisen when Erhard was Bavarian Economics Minister (the decision taken by the Anglo-Saxon allies in the summer of 1946 to merge the economies of the American and British zones). The British zone had a zonal body for economic administration, advised by a German council called the Zonenbeirat. This enabled German political parties to have some influence on the 
British zone's economic administration. The most powerful force at this time in the British zone was the Social Democrats (SPD).

In September 1947, Erhard was appointed to run the Special Bureau for Monetary and Currency Matters. In order to give the population real incentives to produce more goods, he believed that there should be a drastic reduction in money supply. He ran into opposition from Gunter Keiser of the Economics Administration, who said that even though the currency reform was radical, it would not enable them to dispense with controls. Erhard had set the main lines of direction for his bureau. The Bureau was to draw up a blueprint for currency reform which would be presented to the Allies (Americans) and in April 1948 the 'Hamburg Plan' was produced. Experts involved in Erhard's Special Bureau were among those called to secret discussions with the Americans in April and May 1948, and their representations do seem to have eased the impact of currency reform on the German public. Erhard eventually became the director of economic policy in Bizone, and ultimately West Germany.

In short, soon after the Second World War, Germany re-introduced a market economy to exercise severe and stringent controls over cartels. After the currency reform (in 1948), the government decided to bring in the social market economy to characterise economic policy. The market economy had a social goal and believed that consumer protection should be given high priority. The Monopolies Commission and many economists contributed to the development of the German market economy and a fair social order (Hax et al., 1996, p. 66).

According to Cook (2013, p. 495), Soziale Marktwirtschaft, or the SME is a political program and an empirical concept used to describe West Germany's economic system since 1949 and that of re-united Germany economic system since 1990. In general terms, it is a capitalist market economy where imperfections of the market are compensated for by systematic economic and social policies.

It was established in 1948, before the Federal Republic of Germany was founded. In April 1948, the European Recovery Program (Marshall Plan) integrated the reconstruction of the West German economy into the economic recovery of Western Europe. The conservatives won the elections of 1949 by a small margin to form the first West German Cabinet. SME became the economic philosophy of the Federal Republic of Germany. Erhard, who shaped West Germany's economic policy as Minister of Economics from 1949 to 1963, and other liberals argued that the market economy was anyway 'social' as it optimized the allocation of resources. Konrad Adenauer, chancellor from 1949 to 1963, said that the social market economy was a new approach that combined a market economy with systematic social policy. 
Later on, the Social Democrats who came to power as junior partners in the great coalition government (1966-69) and senior partners in the social-liberal coalition government (1969 to 1982) propagated their own model of a social market economy. The stabilization law of 1967, designed by economics minister Karl Schiller (1911-96), defined price stability, full employment, economic growth, and balance-of-payments equilibrium as objectives of economic policy.

The conservative-liberal government that replaced the social-liberal coalition in 1982 promised yet another reform of the social market economy. Even though the reunification in 1990 confirmed the political attractiveness of the social market economy, the economic performance was disappointing. In the current situation, SME is challenged by neo liberal philosophy.

The German system was always different from Anglo-American free market model. This was because of (i) its 'latecomer' status and (ii) the power and influence of the trade unions and socialist movement. As Taberner (2004, p. 3) mentions in an essay in the Frankfurter Rundschau, Heinz Bude reflected on what the decade following German unification had brought for people who had grown up in the 'old' West Germany pre1990:

'That practical little West Germany erected around the worker as the leading actor on an exemplary path to modernization appeared to be losing its way in a globalised world of capital, information and goods'.

Peter Thompson speculated that East Germans on the eve of unification,

'imagined they would get the West Germany of the 1950s, but got that of the 1990s. Germans from both east and west would soon discover that the 'new' Federal Republic would preserve few of the certainties that had often been taken for granted in the 'old' West Germany'.

In the 1990s, the 'German model' came to be challenged by the neo-liberal free-market philosophies which had become dominant in the US and UK in the wake of the redefinition of workers' rights, supply-side reforms and reliance on monetary policy in the era of Ronald Reagan and Margaret Thatcher. For instance, the 'old' West German mode of industry-wide collective bargaining appeared to be increasingly outdated. Certainly, what Paque refers to as the 'Americanisation' of the Eastern labour market was one of a number of areas in which the East seemed to be ahead of the 'old' West Germany, as Lawrence McFalls proposes, 'on their common path to a neo-liberal global society' (2004, p. 4). 
As Luo (2012, p. 432) claims, the U.S mode run on a free market which banks and enterprises have weal property rights restricted, mainly depending on short-term debt to contact and by the strict legal system to resolve disputes, so enterprise funds mainly from self-accumulation, direct ownership of business enterprises securities and credit guarantee for enterprises to eliminate possible risks.

\section{Social Market Economy and SDM in Europe}

Does Europe or the European Union have a social model? There are at least three or four different welfare systems in Europe: a Scandinavian or social democratic model, a conservative-corporatist model, a Latin or Mediterranean model, an Anglo-Saxon model according to Berend (2010, p. 251) and a social market (economic restructuring). This is partly a response to the social model that ensures employment.

Delors argued that Europe required, 'an organized space endowed with common rules to ensure economic and social cohesion' (quoted in Ross, 1995: 43).

Sweden, having maintained a position outside of the European Community throughout most of the post-war period, the SAP Government announced in 1990 that it would be applying to join the EC, witnessing the party leadership argue (in debates on both the 1994 and 2003 referendums) on accession to the EU and EMU membership, that Swedish integration within the European Union would safeguard the social provisions of the Swedish model. In Italy, the promise held by a unified 'European Left' represented a key source of optimism for the Italian Communists. The goal of Social Europe as an antidote, to the pressures of globalization, has become central to the European agenda of 'new' social democratic parties. It can be concluded that SME and SDM is a response to Soviet challenges (reflection of Keynesian New Dale Policy).

The main argument is that SME believes that the government should not intervene in the production system whereas SDM states the opposite. However, similarities can be found as well. For example, when it comes to aspects related to distribution and social welfare, both models agree that the Government should intervene.

\section{Post War Germany and SME}

The German economy was destroyed during the war period. With the reduction of industrial production, Germany lost part of its success to Soviet. The relatively slow and lengthy recovery after World War I was due to the negative effects of hyperinflation in contrast with the repressed inflation and the price controls which were introduced after World War II (Mendershausen, 1955). When the paths of output after the currency 
reforms in 1923 and 1948 are compared, similarly fast rates of growth are found in the period 1923-28 and 1948 onwards.

Wolf (1993) is correct when he states that an important element of the success of the post-World War II West German economy is fortune. Others (Giersch, Paque, Schmieding, 1992) have commented that 'it was only through a number of fortuitous circumstances that an Ordoliberal (i.e., market economy) programme could finally be implemented' in West Germany and a socialist political alternative with significant State intervention and planning be avoided (IFO Institute for Economic Research Sakura Institute of Research 1997).

Cosgrove (1996, p.15) claims that post-World War II period saw major U.S policy initiatives as the United States ascended along with the Soviets to fill the large power vacuum created by defeat of the Germans and Japanese in World War II. The foundations for policy development of free trade, investment, foreign aid, development of multilateral institutions, and arms control had been laid over previous decades.

As President Wilson added yet another dimension to the conduct of U.S foreign policy by injecting ideals and morality for intervention; U.S involvement in World War I was justified in part by high-minded principles espoused by Wilson. By the end of World War I, the United States had established itself as a major power in the Western Hemisphere and in Europe. If U.S involvement in World War 1 is measured against Wilson's 'lofty' goals, it proved to be a failure. It changed the role of the United States in the international system and set the stage for active U.S engagement during and following World War II (Hardt \& Kaufman 1995 p. 454)

Zubok (2007, p. 62) opines that Germany's division was one of the most striking outcomes of the clash between the Soviet Union and the Western democracies. The top Soviet political Commissar in East Germany, Vladimir Semenov, recalled in the 1960s the 'subtle diplomatic moves' that Stalin made. Evidence shows that Stalin and Soviet elites never entertained the idea of a neutral Germany.

East Germany became the most troubled link of the Soviet empire. Stalin felt it was vital to blame the split of the German nation on the Western powers. The Soviets concealed the gradual integration of East Germany into the Soviet empire, leaving the border between East and West Germany open. Thus, Germany turned into a place of relatively open competition between free market and Communist systems. Stiftung (1982, p. 91) claims that in Germany, the SME has stood the test of 30 years. In Asiatic countries, the various so-called great leap forward to force the pace of economic growth and catch up with world levels were invariable leaps to failure. Even in neighboring 
European countries, experiments in economic order have not been very successful (eg: France's planification).

Consequently, Europe's SME has not been subjected to varying treatment. This may be due to the success of free market policies which lessened the appeal of the alternative social order. SME furnishes not only freedom of trade but also freedom of movement for people. The wide range of goods and services available to West German consumers is one of its achievements. Muresan (2014, p. 309) claims that today, Germany believes that the future of SME is a 'spiritual allegiance of our entire system'.

Muresan (2014, p. 159) mentions that by implementing the SME, it was hoped that a 'high degree of secured prosperity for the entire population would be brought about and, as a social subsystem should be compatible with the fundamental values and goals established by the free and democratic state and social order'. A reflection of the original system built and practiced in Western Germany (1948-1990) shows that the SME is similar to a construction sustained by three main pillars: market economy, social order and ecology.

Muresan (2014, p. 165) explains that the SME envisages the achievement of a market economy-driven order without redistributive State intervention. Its implementation is quite flexible. The SME model was influenced by social and liberal policies of the different Governments in power. The State can apply social order only to a limited extent, because it depends on the financial resources it can get from its taxpayers. In Germany, the market economy prevails over the social order. This is the reason why at least as long as the current Federal Constitution is in force, Germany firstly remains a free and only secondly a social society.

There was economic development in Germany as a result of the SME. People began to run the economy under Christian democratic government. The conservative Christian Democratic Union (CDU) and Christian Social Union (CSU) parties adopted Erhard's free market doctrine under the name of 'social market economy'.

\section{Why cannot SME be emulated in the South?}

The SME model worked in exceptional contexts in Germany and Austria in the postWorld War period. However, even in its birth place, the economic policies have now deviated from SME principles. Moreover, the economic policies that Germany now advocates to relatively poor countries in the EU are totally against the SME model. In this backdrop one may justifiably ask: Does the SME represent a viable economic model in the current globalized world? Can it be emulated in the Global South where the context is significantly different? In this section we intend briefly to answer the second question. 
There are 3 major reasons as to why SME cannot be emulated in the South. One of the major reasons is because the globalised system and neo liberal policy framework go against SME principles. The system should be properly aimed at increasing profit. Since high taxes reduce profit, investment will be discouraged. Therefore, since the 1970's and 1980's, there was a high reduction of direct tax in the era of Ronald Reagan and Margaret Thatcher. Thus, the issue of welfare provided by the Government remained problematic.

Secondly, underdeveloped markets are another barrier. The markets in the Southern countries are generally inadequate. SME is designed assuming that markets are perfect. Thus, there is a mismatch between the market condition and plan. With underdevelopment as a cause, markets do not develop. Thus, SME argues that markets may reduce. In countries such as Korea and Taiwan, the absence of a proper market system was a major barrier.

Last but not least, a State controlled by merchant and finance bourgeois is quite challenging. In the underdeveloped setup, the class structure of the upper layers is quite different. All of these reasons should be considered. The most important sectors consists of merchants and finance, not industrial. There is a tendency for capital to move to financing, insurance, trading and other such areas. It is not a hidden fact that this will not help for development purposes. The industrial sector should be focused on development if that is the aim.

\section{REFERENCES}

Ayeshmantha, H 2016, 'Social Market Economy Holds The Key- Harsha', The Sunday Leader. Retrieved: April 18, 2016, from

http://www.thesundayleader.lk/2015/08/30/social-market-economy-holds-the-keyharsha/

Bailey, D 2009, The Political Economy of European Social Democracy: A critical realist approach, Routledge, Oxon

Berend, I 2010, Europe since 1989, Cambridge University Press, Cambridge

Cook, B 2013, Europe since 1945: An Encyclopedia, Routledge, New York

Cosgrove, M 1996, The Cost of Winning Global Development Policies and Broken Social Contracts, Transaction Publishers, New Jersey

Crafts, N \& Toniolo, G 1996, Economic Growth in Europe since 1945, The press syndicate of the University of Cambridge, Cambridge 
Hardt, J \& Kaufman, R 1995, East-Central European Economies in Transition, M.E. Sharpe Inc, New York

Hax, H, Klenner, W, Kraus, W, Matsuda, T, Nakamura, T 1996, Economic Transformation in Eastern Europe and East Asia: A Challenge for Japan and Germany, Springer-Verlag, Berlin

Hildebrand, D 2009, The Role of Economic Analysis in the EC Competition Rules, $3^{\text {rd }}$ edn, Kluwer Law International, The Netherlands

Hook, J 2004, Rebuilding Germany: The Creation of the Social Market Economy1945- 1957, The Press Syndicate of the University of Cambridge, United Kingdom

Ifo Institute for Economic Research Sakura Institute of Research 1997, A Comparative Analysis of Japanese and German Economic Success, Springer, Japan

Kaufman, J 2010, A Concise History of U.S. Foreign Policy, $2^{\text {nd }}$ edn, Rowman\& Littlefield Publishers Inc, United Kingdom

Koslowski, P 1998, The Social Market Economy: Theory and Ethics of the Economic Order, Springer-Verlag, Berlin

Luo, J 2012, Soft Computing in Information Communication Technology, Springer, Heidelberg

Muresan, S 2014, Social Market Economy: The Case of Germany, Springer International Publishing, Switzerland

Nicholls, A 1994, 'Ludwig Erhard and the Origins of the Social Market Economy', Freedom With Responsibility: The Social Market Economy in Germany 19181963, Oxford University Press Inc, New York, pp. 151-158

Rhodes, B 2001, United States Foreign Policy in the Interwar Period 1918-1941: The Golden Age of American Diplomatic and Military Complacency, Praeger Publishers, Westport

Roberts, G 2000, German Politics Today, Manchester United Press, United Kingdom

Stiftung, L 1982, Standard Texts on the Social Market Economy, Gustav Fischer, New York

Taberner, S 2004, German Literature in the age of globalisation, University of Birmingham Press, Birmingham 
Tribe, K 1995, Strategies of Economic Order: German Economic Discourse 1750-1950, Cambridge University Press, New York

Zubok, V 2007, (A Failed Empire) The Soviet Union in the Cold War from Stalin to Corbachev, The University of North Carolina Press, USA

'Germany’s Orderly Social Market' 2009, BBC News, 17 January. Retrieved: April 27, 2016 from

http://news.bbc.co.uk/2/hi/programmes/from_our_own_correspondent/7837266.stm

'PM articulates programme to create highly competitive social market economy in Sri Lanka- Harsha' 2015, The Island, 5 November. Retrieved: June 14, 2016, from http://island.lk/index.php?page_cat=article-details\&page=articledetails\&code_title $=134798$

'Sri Lanka putting together social market economy model' 2015, The Sunday Times, 4 October. Retrieved: April 18, 2016, from http://www.sundaytimes.lk/151004/business-times/sri-lanka-putting-togethersocial-market-economy-model-166355.html

'Sri Lanka urged to bring legislations for policy reforms: Harsha De Silva' 2015, Lanka Business Online, 5 November. Retrieved: June 14, 2016, from http://www.lankabusinessonline.com/sri-lanka-urged-to-bring-legislations-forpolicy-reforms-harsha-de-silva/

'Sri Lanka's new political front releases its five-fold development plan for next five years' 2015, ColomboPage, 23 July. Retrieved: June 14, 2016, from http://www.colombopage.com/archive_15B/Jul23_1437658944CH.php

Ayeshmantha, H 2016, 'Social Market Economy Holds The Key- Harsha', The Sunday Leader. Retrieved: April 18, 2016, from http://www.thesundayleader.lk/2015/08/30/social-market-economy-holds-the-keyharsha/

Kuruwita, R 2015, 'UNFGG heads for social market economy', Ceylon Today. Retrieved: June 14, 2016, from http://www.ceylontoday.lk/51-99086-news-detailunfgg-heads-for-social-market-economy.html

Ministry of National Policies and Economic Affairs, 2015 Economic Policy Statement made by Hon Prime Minister, Ranil Wickremesinghe in Parliament on $5^{\text {th }}$ November 2015. Retrieved: June 14, 2015 from http://www.mnpea.gov.lk/web/index.php?option=com_content\&view=article\&id=6 
SLJER Volume 4 Number 1, December. 2016

2:economic-policy-statement-made-by-hon-prime-minister-ranil-wickremesinghein-parliament-on-5th-november-2015\&catid=20\&Itemid=101\&lang=en

Sirimane, S 2015, 'PM's economic policy receives mixed reviews', Sunday Observer. Retrieved: June 14, 2016, from

http://archives.sundayobserver.lk/2015/11/08/fin01.asp 